\title{
Effectiveness of Non- Governmental Organizations (NGOs) programs in the integration of multi-disability into the local community
}

\section{Ahmed Mohamed Atia Morsy (PhD)}

Assistant Professor, Faculty of Social Work Aswan University

\section{Mabroka Mahmoud Mohamed Olik (PhD)}

Assistant Professor, Faculty of Social Work Helwan University 


\section{Effectiveness of Non- Governmental Organizations (NGOs) programs in the integration of multi-disability into the local community}

Ahmed Mohamed Atia Morsy (PhD)

Assistant Professor, Faculty of Social Work Aswan University Mabroka Mahmoud Mohamed Olik (PhD)

Assistant Professor, Faculty of Social Work Helwan University

\section{ABSTRACT:}

The study aims at specifying the programs NGOs provide to multi-disability, also estimating the level of the effectiveness dimensions of NGOs programs in the integration of multi-disability into the local community, Specifying opinions of service providers in the effectiveness of NGOs programs in the integration of multidisability into the local community. This study belongs to the evaluative studies, It has used a method of a comprehensive social survey to multi-disability and their heads of families whose number is (110) persons, (55) for each, also service providers whose number is (28) persons ,Both researchers carried out a survey on multi-disability and their heads of families and a survey on service providers .The study concluded that the most important programs offered by NGOs for multi-disability to integrate them into the local community are the following programs(educational, social, sports, cultural, religious, health, economic programs), The study also proved that the effectiveness of these programs contributes to the following (modify the attitudes ,change behavior patterns, face the problems, develop the knowledge, satisfy the needs, give new experiences and skills)of multi-disability into the local community, so the study has proved authenticity of its objectives and hypotheses.

\section{KEY WORDS}

Effectiveness - programs - NGOs - integration - multi-disability.

\section{INTRODUCTION:}

The human factor represents the real impetus of development ,which entitles giving due care to the development of The human resources on the basis that man is the end and the means of the process of development . Giving due care to the disabled is one of the factors of the human development as they are one of the sections of the society whose energies were disrupted because of malfunction of one of the body systems, so giving due care to the disabled has become an 
urgent need to enable them to lead a normal productive life (Fahmy,2000: p7).

According to the changes which societies suffer from and the different economic, social ,health and cultural conditions between societies, we notice the difference and change in the number and percentage of the disabled between societies, and in the same society (Cook, M., \& pamele, T, 2002, p80).

The number of the disabled around the world is about one billion persons, that is about $(15 \%)$ of the world population, (93) of them are disabled children, (13) of them with difficult disabilities .The World Health Organisation population survey (2012) indicates that (785) million persons around the world aged 15 and above have a disability and (110) of them have functional disabilities (WHO, 2012).

As for the Egyptian society, the Central Agency for Population Mobilisation and Statistics said in its annual report (2010) that the percentage of the disabled in Egypt varies. Physical disability is $(34.2 \%)$,mental disability is $(22.51 \%)$, multiple disabilities are $18.3 \%$, hearing disability is (10.4) and finally visual disability is $(13.33 \%)$. Hassan (2012) P2,3. The percentage of the disabled in the Egyptian society has increased to $(10.67 \%)$ of the total population starting (5) years ago or more ( the Central Agency, 2017).

As a result to the increasing number of the disabled, taking care of them has become an urgent necessity as a compensation to them for their disabilities and enabling them to live normally and supporting helping them to get their rights .The study of Abdel Ghafar (2008) has highlighted the importance of taking care of the disabled and developing their experiences and skills and creating job opportunities helping them to have the suitable work for their abilities and energies which enables them to integrate into the society.

What made the issue of disability more serious is that it is (multidisability) and the resulting serious psychological and social problems for this section which need to be studied, as the multi-disability are those who have varied patterns of disabilities, such as the deaf and blind with physical disabilities , or any other combination of two disabilities or more ( Al Zayyat, 2009, p 106).

It can be said that multi-disability do not suffer from problems of personal adjustment as far as social adjustment problems in the outside community, The looks of disgusting and sympathy the persons with multiple disabilities receive from passers-by kill in them every 
hope affecting self compatibility in accepting their disability (Alsurugi, Aboulmaati , 2006 ,P 306).

The results of the study of Shalaby (2007) also confirmed that multi-disability are exposed to a number of problems such as neglect, rejection, indifference and cruelty in their treatment, in addition to the problems of social relations.

Multi-disability are not different from any other human so they need to be accepted by others as worthy people, also they need to accept themselves (John, M., 2002, p61) .

This requires the necessity to face those problems and satisfy their different needs through social support and providing financial support and helping them configure social relationships, communicate with others, and help them participate in daily life, also providing educational and material facilities and providing jobs for them (Cook , M., \& pamel, t. 2002 ) .

The study of Hori, S., (2003) confirmed that there is a difference and contradiction between the actual needs and services available for persons with multiple disabilities, lack of enough medical and therapeutic services and instruments, in addition to community and legislative constraints preventing dealing with these needs properly.

Also A lot of Multi-disability do not get the proper health care ,which hinders them play their roles in society (Ecken rode, J. et al, 2008, p2).

So we must vary the methods of care provided to them by the communities, whether on the preventive level to reduce disability or the developmental level to take advantage of their potential and their abilities to use them properly and return them to production workflow and integrate them into society and improve their quality of life (Janet, W., \& Frank, k., 2006, p6) .

The study results of Al-Rashidi (2006) have shown the need to provide various programs for persons with multiple disabilities, and helping them communicate with others to benefit from their expertise in solving their problems and give them an opportunity to express their problems and take appropriate decisions to face them, that is besides providing the appropriate educational programs to their abilities that give them different societal experiences.

The results of the of study Talat (2008) confirmed the need to develop the social interaction skills for persons with multiple disabilities, and entertainment programs, and also educational programs in addition to the development of social integration 
programs and making them available in accordance with the regulations and parameters to ensure that through putting into consideration the number of the multi-disability and responding to their different complaints in the non-governmental organizations.

The NGOs play a vital role in facing the social problems of the multi-disability as one of the marginal groups on both local and national levels provided there are cooperative relations in their programs to influence the policies and decisions of the government to face all the social problems of this group, implement suitable programs for them and following them up while benefitting from such programs, rehabilitation and retraining of this group through the flexibility and effectiveness of the programs provided and ease of access as one of the rights of protecting them, this is confirmed in the study (Davied, 1., 2002).

The results of the study of Hinton, s., (2002) also confirmed that the NGOs contribute to fulfilling the emotional and social needs of these vulnerable groups, in addition to helping them on sound scientific thinking, and providing them with different knowledge and eradicating their illiteracy, in addition to helping them invest their abilities and developing the skills of their craft.

The results of the study Michael, 1., (2002) confirmed that the NGOs work to provide social support for multi-disability socially, economically and politically as individuals within society by providing real opportunities for them to strengthen and protect their rights and express their views, which modifies their negative attitudes towards their community and increases their self- confidence.

Program effectiveness means "the organization's ability to achieve aims or targeted result of a certain program and helping client to achieve his own aims in a scheduled time (Barker, 1998, p 47).

The NGOs for multi-disability contributes to achieving their community integration through facing the psychological and social pressures that could face them as the continued interaction with multidisability and society in the framework of actual practice for the disabled gives them psychological satisfaction and self-confidence and trust in others who deal with them within the framework of love and affection and security (Menkerios , 2011, P 157).

The results of the study Douglas (2006) also confirmed a high level of general satisfaction among the parents of the multi-disability with the integration programs as these programs contribute to more of 
their participation in society development, modifying their negative attitudes and also satisfying their psycho-social needs .

Moreover, the integration and effectiveness of the programs are provided only through participation of the multi-disability and giving them opportunities as others within the community, this requires of course from the community to adopt more positive attitudes towards them (Al-Sherbini , 2011, p 202).

The results of the study of Michel, k., (2004) recommended that it be necessary to give due attention to the social care services for the multi-disability, in addition to necessity to give the opportunity to participate in the programs and the activities provided for them, putting into consideration their dignity which in turn contributes to configuring new successful sociable relationships through changing their behavior patterns.

Multi-disability getting appropriate training opportunities and employment, will eventually lead to improving their clinical status and feeling of satisfaction, eventually leading to modifying their attitudes towards the local community and this is confirmed by the results of the study of Penn (1995).

The results of the study Seals (1997) also confirmed that violent behavior was almost non-existent in children with multiple disabilities by providing jobs and the socialization of these children.

Integration also achieves a balance among multi-disability and with their community, which helps them achieve their psycho-social compatibility ( Ghabarri , 2003, P136).

The study of Khawla \& Cristina (2013) has confirmed that multidisability need to have a feeling of safety in their social community to achieve their psycho-social compatibility.

This is emphasized by the study of Deborah (1992) where it noted that the general practice of social works to help disabled children to face their problems and satisfy their needs and reduce the sense of isolation and increase the chances of successful relationships with the social environment.

The results of the study seeger (2008) confirmed that the professional role of the social workers is achieving the first integration processes for multi-disability, giving them experience and selfconfidence, modifying their negative attitudes, facing their problems, satisfying their needs and developing their life experiences and skills so they are able to take part in the society developing programs. 
In the light of the foregoing, the study tries to answer the following questions (what are the programs provided by the nongovernmental organizations to multi-disability in the local community, What is the level of the effectiveness dimensions of NGOs programs in the integration of multi-disability into the local community).

Specifying opinions of service providers in the effectiveness of NGOs programs and its role in the integration of multi-disability into the local community.

Importance of the study:

1- The Egyptian society gives due care to the disabled in General and particularly those with multiple disabilities and studying their problems and their needs so it devoted the year 2018 a year for the disabled with different disabilities.

2-The effective role that could be played by NGOs , supplementing governmental role in the field of social care for the disabled and the multi-disability through creating and planning local and human development programs for them.

3- The effectiveness of social, educational, health, economic and recreational programs provided by the NGOs for the multidisability contribute to (satisfying their needs, facing their problems, modifying their negative attitudes and giving them new skills and experiences) that help to integrate them into the local community.

\section{Research Goals:}

1-Specifying the programs the NGOs provide to multi-disability in the local community

2- Estimating the level of the effectiveness dimensions of NGOs programs in the integration of multi-disability into the local community.

3. Specifying opinions of service providers of the effectiveness of NGOs programs and its role in the integration of multi-disability into the local community.

\section{Study hypotheses:}

1-The first hypothesis of study: It is expected that the level of the effectiveness dimensions of NGOs programs in the integration of multi-disability into the local community is advanced. We can test this hypothesis through the following dimensions: (change behavior patterns, develop the knowledge, modify the attitudes, give new experiences and skills, satisfy the needs, face the problems) of multi-disability into the local community. 
2- The second hypothesis of study:There are no substantial differences giving statistics evidence between the responses of multi-disability and the responses of the heads of families concerning specifying the level of the effectiveness dimensions of NGOs programs in the integration of multi-disability into the local community.

3- The third hypotheses of study: There are no substantial differences giving statistics evidence between the responses of multi-disability in the NGOs concerning specifying the programs the NGOs provided to multi-disability in the local community.

4-The four hypotheses of the study :There are no substantial differences giving statistics evidence between the responses of multi-disability in the the NGOs concerning estimating the level of the effectiveness dimensions of NGOs programs in the integration of multi-disability into the local community.

\section{Theoretical Guidelines of the Research:}

The study relied on indicators to measure effectiveness in accordance with the framework established by Rino J. Patti and identified those indicators in (the ability of programs to bring about a change in the behavior patterns of beneficiaries, the ability of programs to modify or change the attitudes of beneficiaries, the ability of programs to develop and enrich the knowledge of beneficiaries, the ability of programs to give beneficiaries experiences and mastering new skills, the ability of programs to satisfy one of the basic needs of beneficiaries, the ability of programs to face the problems of beneficiaries (Rino J. Patti ,1987, p377). The justifications of the use of this form are that it is one of the evaluation models and fits with the evaluative studies and it is related to measuring the effectiveness of programs and knowing its return, identify the point of view of the beneficiaries of those programs, and determining the Organization's ability to achieve its current objectives and what is expected from it in the future in the scope the external environment, and finally the results of measuring effectiveness are inputs benefiting the development and improvement of programs in the future.

\section{Concepts:}

Effectiveness:It is defined as " the degree at which the program aims are achieved as set previously (Joem. Schriver, 2004, p433).

\section{And effectiveness actually means in this study:}

- The ability of programs to (change behavior patterns, develop the knowledge, modify the attitudes, give new experiences and skills, 
satisfy the needs, face the problems)of multi-disability- in the local community.

Programs: Defined as an organized group of activities designed to reach specific goals . (David Royse \& Others, 2001,p 5).

The programs actually mean in this study:

- A set of programs offered by the non-governmental organizations for multi-disability whether these programs were (social, psychological, education, entertainment, health, sports. Etc)

-Specialists providing these programs represent the work team in the organization and the social worker is a specialist in that area.

NGOs: It is defined as an organization established to achieve certain social objectives, not for profit, including private voluntary and social institutions provided that its the main purpose is not profit ( Barker, ,1998, p 87). and these organizations are founded by residents of a community to solve their problems and develop their communities (Roos , Mary 1995, p156).

\section{The NGOs actually mean in this study:}

-They are NGOs not seeking financial profit.

- They aim to provide social welfare programs for multi-disability to integrate them into the local community.

Integration : It is defined as "a process aims at the disabled self adaptation and with the surrounding social environment through organized scientific effort aiming at creating a positive interaction between a disabled person and individuals and social groups and organizations where he/she lives to participates in the development process (Al-Khatib ,2006, p51).

Integration actually means in this study:

-A process including giving multi-disability the opportunity to participate in the activities and programs of the local community.

- The perfect investment of the capacity and potential of these disabled people and equip them with the desired social values in society and common sense, experiences and skills and the satisfaction of their needs and facing their problems in a way allowing them to participate in the local community activities.

Multi-disability :Also known as the individual who has many types of disabilities simultaneously (Stanley, f., \& stcrst, A., 1993, p231).

Multi-disability actually mean in this study that they are:

- Those people who suffer from more than one type of disability, whether (hearing and motor - motor-visual and hearing and visual deaf and mute). 
- Persons aged 14 to 18 , whether they are male or female.

\section{METHODOLOGY:}

Type of study: this study belongs to the evaluative studies that seek to measure the effectiveness of NGOs programmes in integrating multidisability in the local community.

The method used: the study adopted social survey methodology using a comprehensive inventory method of multi-disability, heads of families, service providers and officials of NGOs .

\section{Study tools: tools for collecting data are:}

(1) Carrying out a survey on multi-disability where both researchers carried out a survey on multi-disability by reference to theoretical heritage, previous studies related to the subject of the study. Both researchers did Virtual honesty to the tool after presentation to number (4) of the members of the staff of the Faculty of social work University of Helwan, Faculty of social work University of Aswan, depending on a minimum of agreement rate $(75 \%)$, deleting some phrases and rephrasing some. According to this the form has been finally phrased. Both researchers have done a reliability statistical survey to a sample of (10) persons of multidisability using the equation of Spearman-Brown Split- half, reliability coefficient is $(0.83)$, and it is an appropriate level of consistency.

(2) Carrying out a survey on multi-disability where both researchers carried out a survey on multi-disability heads of families by reference to theoretical heritage, previous studies related to the subject of the study. Both researchers did Virtual honesty to the tool after presentation to number (4) of the members of the staff of the Faculty of social work University of Helwan, Faculty of social work University of Aswan, depending on a minimum of agreement rate $(75 \%)$, deleting some phrases and rephrasing some. According to this the form has been finally phrased. Both researchers have done a reliability statistical survey to a sample of (10) multi-disability heads of families using the equation of Spearman-Brown Split- half, reliability coefficient is (0.83), and it is an appropriate level of consistency.

(3) Carrying out a survey on service providers where both researchers carried out a survey on service providers in its first draft depending on the the theoretical frame of the study and the previous studies related to the subject of the study. Both researchers did Virtual honesty to the tool after presentation to 
(4) of the members of the staff of the Faculty of social work University of Helwan, Faculty of social work University of Aswan, depending on a minimum of agreement rate $(75 \%)$, deleting some phrases and rephrasing some. According to this the form has been finally phrased. Both researchers have done a reliability statistical survey to a sample of (10) officials using the equation of Spearman-Brown Split- half, reliability coefficient is (0.83), and it is an appropriate level of consistency. Estimating the level of the effectiveness of NGOs programs in the integration of multi-disability into the local community:

to judge the effectiveness of NGOs programs in the integration of multi-disability into the local community, where the beginning and end of the triple scale categories: Yes (three marks), to some degree (two marks), no (one mark), Coded data entered into the computer and to determine the length of triple scale cells (minimum and maximum limits), they calculated the range $=$ maximum value-minimum value $(3-1=2)$, is divided on the scale of cells to get the length cell debugger $(2 / 3=0.67)$ and then add this value to the minimum value in the scale or the beginning of the scale which is 1 to determine the maximum limit of this cell, thus the length of cells is as follows:

\section{Table (1) levels of arithmetic averages}

\begin{tabular}{|l||l||}
\hline \hline If the average value for the phrase or dimension from 1 to less & Low level \\
than 1.67 & \\
\hline \hline If the average value for the phrase or the dimension from 1.67 to & $\begin{array}{l}\text { Medium } \\
\text { level }\end{array}$ \\
less than 2.35 & $\begin{array}{l}\text { A high } \\
\text { level }\end{array}$ \\
\hline \hline If the average value for the phrase or the dimension from 2.35 to \\
3
\end{tabular}

- Statistical analysis methods: The data has been processed through a computer using program (SPSS. V. 17.0) statistical packages for the social sciences, statistical methods were applied as follows: duplicates and percentages, arithmetic average, standard deviation, range, and reliability coefficient (Alpha Cronbach) and Spearman- brown equation Split-half,, (T) test for two separate samples and unidirectional variance analysis.

\section{Areas of study:}

Spatial domain: specified in the NGOs that operate in the field of multi-disability in Cairo and they are (the free Arab opinion association having (13) of multi-disability -Atfaluna our children in Maadi having (16) of multi-disability- the Egyptian society for the development of Children's abilities having (11) of multi-disabilitybasmati Amal( A smile of hope) in Maadi having (15) multi-disability. 


\section{They return the justifications for choosing these associations to:}

- Diversity of programs offered for multi-disability in society and helping them to integrate into society, whether social, economic or educational or health programs. Etc

Sample availability of (multi-disability) who are capable of dealing with researchers to conduct studies.

- Associations approval for the two researchers to conduct the study.

\section{The human area:}

-A comprehensive survey of multi-disability and their heads of families whose number is (110) persons ,(55) for each.

-A comprehensive survey of service providers, social workers and officials of the NGOs whose number is (28) persons.

\section{There are several conditions for selecting that category:}

-Excluding mental disability associated with other disabilities and focusing on the disabled who combines audio and motor disabilities motor and Visual-audio and Visual - deaf and mute .

- Multi-disability are males and females , and The age ranges between (14 to 18 years) to be able to respond to the researchers.

-Multi-disability heads of families must agree to cooperate with the two researchers.

- Service providers must have direct contact with Multi-disability families.

Time area: to be determined in the time period from 25/11/2018 to $1 / 3 / 2019$ to collect data from the field of study.

- Statistical analysis methods :The data has been processed through a computer using program (SPSS. V. 17.0) statistical packages for the social sciences, statistical methods were applied as follows: duplicates and percentages, arithmetic average, standard deviation, range, and reliability coefficient (Alpha Cronbach) and Spearman- brown equation Spli-half, unidirectional variance analysis. 
Print ISSN: 2356-9204 Online ISSN: 2356-9212 Vol 8, Issue 1, June 2019

\section{Results:}

Table (2) The programs of NGOs provided to multi-disability in the local community

\begin{tabular}{|c|c|c|c|c|c|c|c|}
\hline \multirow[t]{2}{*}{ No } & \multirow[t]{2}{*}{ Phrases } & \multicolumn{3}{|c|}{$\begin{array}{l}\text { multi-disability } \\
\mathrm{N}=(55)\end{array}$} & \multicolumn{3}{|c|}{$\begin{array}{c}\text { heads of families } \\
N=(55)\end{array}$} \\
\hline & & $\overline{\mathrm{A}}$ & 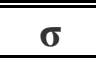 & order & $\overline{\mathrm{A}}$ & 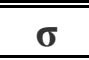 & order \\
\hline 1 & Social programs & 5.29 & 2.43 & 2 & 4.82 & 1.86 & 3 \\
\hline 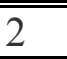 & "Cultural programs & 4.38 & 2.49 & 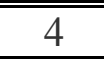 & 4.62 & 2.49 & 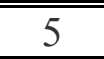 \\
\hline 3 & Sports programs & 4.84 & 2.28 & 3 & 5.29 & 2.31 & 2 \\
\hline 4 & $\begin{array}{l}\text { Technical } \\
\text { programs }\end{array}$ & 3.71 & 2.31 & 7 & 3.71 & 2.43 & 7 \\
\hline 5 & $\begin{array}{l}\text { Religious } \\
\text { programs }\end{array}$ & 4.31 & 2.04 & 5 & 4.16 & 2.28 & 6 \\
\hline 6 & $\begin{array}{l}\text { Educational } \\
\text { programs }\end{array}$ & 5.75 & 2.03 & 1 & 5.47 & 2.04 & 1 \\
\hline 7 & Health programs & 4.18 & 1.86 & 6 & 4.69 & 2.04 & 4 \\
\hline 8 & $\begin{array}{l}\text { Economic } \\
\text { programs }\end{array}$ & 3.53 & 2.04 & 8 & 3.25 & 2.03 & 8 \\
\hline
\end{tabular}

The previous table shows that: The programs of NGOs as specified by multi-disability are: the first order came the educational programs arithmetic average (5.75), second order social programs, arithmetic average (5.29), and finally the economic programs, arithmetic average (3.53).

-The programs of NGOs as specified by multi-disability heads of families are: the first order came the educational programs arithmetic average (5.47), second order Sports programs, arithmetic average (5.29), and finally the economic programs, arithmetic average (3.25).

Table (3) change of the behavior patterns of multi-disability in the local community

\begin{tabular}{|c|c|c|c|c|c|c|c|}
\hline \multirow[t]{2}{*}{ z } & \multirow[t]{2}{*}{ Phrases } & \multicolumn{3}{|c|}{$\begin{array}{l}\text { multi-disability } \\
\qquad \mathrm{N}=(55)\end{array}$} & \multicolumn{3}{|c|}{$\begin{array}{c}\text { heads of families } \\
\mathrm{N}=(55)\end{array}$} \\
\hline & & $\mathrm{A}$ & $\sigma$ & order & $\mathrm{A}$ & $\sigma$ & order \\
\hline 1 & $\begin{array}{l}\text { The programs taught } \\
\text { multi-disability respect for } \\
\text { others ' opinions when } \\
\text { discussing } \\
\text { community issues }\end{array}$ & 2.58 & 0.53 & 1 & 2.62 & 0.53 & 1 \\
\hline
\end{tabular}




\begin{tabular}{||lcc||}
\hline \hline Egyptian Journal of Social Work (EJSW) & http://ejsw.journals.ekb.eg \\
Print ISSN: $2356-9204$ & Online ISSN: $2356-9212$ & Vol 8, Issue 1, June 2019 \\
\hline \hline
\end{tabular}

\begin{tabular}{|c|c|c|c|c|c|c|c|}
\hline \multirow{2}{*}{ z } & \multirow[t]{2}{*}{ Phrases } & \multicolumn{3}{|c|}{$\begin{array}{l}\text { multi-disability } \\
\mathrm{N}=(55)\end{array}$} & \multicolumn{3}{|c|}{$\begin{array}{c}\text { heads of families } \\
\mathrm{N}=(55)\end{array}$} \\
\hline & & $\mathrm{A}$ & $\sigma$ & order & $\mathrm{A}$ & $\sigma$ & order \\
\hline 2 & $\begin{array}{l}\text { The programs helped } \\
\text { multi-disability to adapt } \\
\text { with others in the } \\
\text { community }\end{array}$ & 2.45 & 0.54 & 3 & 2.49 & 0.54 & 3 \\
\hline 3 & $\begin{array}{l}\text { The programs gave multi- } \\
\text { disability emotional } \\
\text { equilibrium when dealing } \\
\text { with others in my } \\
\text { community }\end{array}$ & 2.33 & 0.75 & 5 & 2.36 & 0.75 & 5 \\
\hline$\overline{44}$ & $\begin{array}{l}\text { The programs led multi- } \\
\text { disability to participate in } \\
\text { local community } \\
\text { development activities }\end{array}$ & 2.51 & 0.63 & 2 & 2.6 & 0.6 & 2 \\
\hline 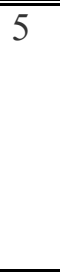 & $\begin{array}{l}\text { The programs enabled } \\
\text { multi-disability to } \\
\text { configure a successful } \\
\text { social relationships with } \\
\text { others in the local } \\
\text { community }\end{array}$ & 2.4 & 0.66 & 4 & 2.47 & 0.66 & 4 \\
\hline & 1/ Dimension & 2.45 & "0.33 & $\begin{array}{l}\text { High } \\
\text { level }\end{array}$ & 2.51 & 0.35 & $\begin{array}{l}\text { High } \\
\text { level }\end{array}$ \\
\hline
\end{tabular}

The previous table shows that: The level of change the behavior patterns as specified by multi-disability is high with arithmetic Average (2.45), first came the programs taught multi-disability respect for others ' opinions when discussing local community issues arithmetic Average (2.58), The second order came The programs led multi-disability to participate in local community development activities with arithmetic Average (2.51), and finally, The programs gave multi-disability emotional equilibrium when dealing with others in my community -arithmetic Average (2.33).

-The level of change the behavior patterns as specified by multi-disability heads of families is high with arithmetic Average (2.51), first came the programs taught multi-disability respect for others ' opinions when discussing local community issues arithmetic Average (2.62), The second order came The programs led multidisability to participate in local community development activities with arithmetic Average (2.6), and finally, The programs gave multidisability emotional equilibrium when dealing with others in my community -arithmetic Average (2.36). 
Print ISSN: 2356-9204 Online ISSN: 2356-9212 Vol 8, Issue 1, June 2019

Tale (4) multi-disability knowledge development in the local community

\begin{tabular}{|c|c|c|c|c|c|c|c|}
\hline \multirow[t]{2}{*}{ No } & \multirow[t]{2}{*}{ Phrases } & \multicolumn{3}{|c|}{$\begin{array}{l}\text { multi-disability } \\
\mathrm{N}=(55)\end{array}$} & \multicolumn{3}{|c|}{$\begin{array}{l}\text { heads of families } \\
\mathrm{N}=(55)\end{array}$} \\
\hline & & $\mathrm{A}$ & $\sigma$ & order & $\mathrm{A}$ & $\sigma$ & Order \\
\hline 1 & $\begin{array}{l}\text { The programs } \\
\text { develop multi- } \\
\text { disability knowledge } \\
\text { linked to the local } \\
\text { community problems }\end{array}$ & 2.49 & 0.63 & 1 & 2.56 & 0.6 & 1 \\
\hline 2 & $\begin{array}{l}\text { The programs helped } \\
\text { multi-disability to } \\
\text { learn about current } \\
\text { events in the } \\
\text { community }\end{array}$ & 2.16 & 0.6 & 5 & 2.24 & 0.61 & 5 \\
\hline 3 & $\begin{array}{l}\text { The programs gave } \\
\text { multi-disability } \\
\text { knowledge of services } \\
\text { provided by other } \\
\text { Community } \\
\text { institutions in the } \\
\text { local community }\end{array}$ & 2.47 & 0.6 & 3 & 2.51 & 0.6 & 2 \\
\hline 4 & $\begin{array}{l}\text { The programs gave } \\
\text { multi-disability the } \\
\text { knowledge I need in } \\
\text { my practical life. }\end{array}$ & 2.44 & 0.6 & 4 & 2.45 & 0.6 & 4 \\
\hline 5 & $\begin{array}{l}\text { The programs } \\
\text { supplied multi- } \\
\text { disability with the } \\
\text { knowledge related to } \\
\text { their community } \\
\text { rights. }\end{array}$ & 2.49 & 0.72 & 2 & 2.49 & 0.72 & 3 \\
\hline & Total Dimension & 2.41 & 0.3 & $\begin{array}{l}\text { High } \\
\text { level }\end{array}$ & 2.45 & 0.33 & $\begin{array}{l}\text { High } \\
\text { level }\end{array}$ \\
\hline
\end{tabular}

The previous table shows that: The level of knowledge development as specified by multi-disability is high with arithmetic Average (2.41), the first came The programs develop multi-disability knowledge linked to the local community problems with arithmetic average (2.49), the second came The programs supplied multi-disability with 
the knowledge related to their community rights with arithmetic average (2.49), finally The programs helped multi-disability to learn about current events in the community with arithmetic average (2.16).

- The level of knowledge development as specified by multi-disability heads of families is high with arithmetic Average (2.45), the first came The programs develop multi-disability knowledge linked to the local community problems with arithmetic average (2.56), the second came The programs gave multi-disability knowledge of services provided by other Community institutions in the local community with arithmetic average (2.51), finally The programs helped multidisability to learn about current events in the community with arithmetic average (2.24).

Table (5) modifying the attitudes of multi-disability towards the local community.

\begin{tabular}{|c|c|c|c|c|c|c|c|}
\hline \multirow[t]{2}{*}{ No } & \multirow[t]{2}{*}{ Phrases } & \multicolumn{3}{|c|}{$\begin{array}{c}\text { multi-disability } \\
\mathrm{N}=(55)\end{array}$} & \multicolumn{3}{|c|}{ heads of families $\mathrm{N}=(55)$} \\
\hline & & A & $\Sigma$ & order & A & $\boldsymbol{\sigma}$ & Order \\
\hline 1 & $\begin{array}{l}\text { The } \\
\text { programs } \\
\text { helped multi- } \\
\text { disability to } \\
\text { change their } \\
\text { negative } \\
\text { attitudes } \\
\text { towards } \\
\text { others in the } \\
\text { local } \\
\text { community }\end{array}$ & 2.62 & 0.59 & 1 & 2.65 & 0.58 & 1 \\
\hline 2 & $\begin{array}{l}\text { The } \\
\text { programs } \\
\text { Contributed } \\
\text { to modifying } \\
\text { multi- } \\
\text { disability } \\
\text { negative } \\
\text { ideas } \\
\text { towards their } \\
\text { local } \\
\text { community }\end{array}$ & 2.42 & 0.66 & 4 & 2.44 & 0.66 & 4 \\
\hline
\end{tabular}




\begin{tabular}{|llc||}
\hline \multicolumn{2}{|l|}{ Egyptian Journal of Social Work (EJSW) } & http://ejsw.journals.ekb.eg \\
Print ISSN: $2356-9204$ & Online ISSN: 2356-9212 & Vol 8, Issue 1, June 2019 \\
\hline \hline
\end{tabular}

\begin{tabular}{|c|c|c|c|c|c|c|c|c|c|}
\hline \multirow[t]{2}{*}{ No } & \multirow[t]{2}{*}{ Phrases } & \multicolumn{3}{|c|}{$\begin{array}{l}\text { multi-disability } \\
\mathrm{N}=(55)\end{array}$} & \multicolumn{5}{|c|}{ heads of families $\mathrm{N}=(55)$} \\
\hline & & $\overline{\mathrm{A}}$ & $\bar{\Sigma}$ & order & $\overline{\mathrm{A}}$ & & 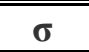 & & Order \\
\hline 3 & $\begin{array}{l}\text { The } \\
\text { programs } \\
\text { Changed } \\
\text { multi- } \\
\text { disability } \\
\text { pessimistic } \\
\text { outlook } \\
\text { towards their } \\
\text { local } \\
\text { community } \\
\end{array}$ & 2.44 & 0.54 & 2 & 2.47 & & 0.54 & & 3 \\
\hline 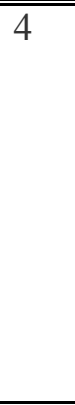 & $\begin{array}{l}\text { The } \\
\text { programs } \\
\text { increased } \\
\text { multi- } \\
\text { disability } \\
\text { self- } \\
\text { confidence in } \\
\text { the local } \\
\text { community } \\
\end{array}$ & 2.44 & 0.57 & 3 & 2.49 & & 0.57 & & 2 \\
\hline 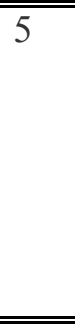 & $\begin{array}{l}\text { Multi- } \\
\text { disability } \\
\text { now take } \\
\text { part in the } \\
\text { local } \\
\text { community } \\
\text { activities } \\
\end{array}$ & 2.35 & 0.7 & 5 & 2.4 & & 0.71 & & 5 \\
\hline \multicolumn{4}{|c|}{ Total Dimension } & 2.45 & 0.31 & $\begin{array}{l}\text { High } \\
\text { level }\end{array}$ & 2.49 & 0.35 & $\begin{array}{l}\text { High } \\
\text { level }\end{array}$ \\
\hline
\end{tabular}

The previous table shows that: The level of modifying the attitudes as specified by multi-disability is high with the arithmetic average (2.45), first came: The programs helped multi-disability to change their negative attitudes towards others in the local community arithmetic average (2.62), and came second The programs Changed multi-disability pessimistic outlook towards their local community with arithmetic average (2.44), and finally, multi-disability now take part in the local community activities with arithmetic average (2.35). - The level of modifying the attitudes as specified by multi-disability heads of families is high with the arithmetic average (2.49), first came: The programs helped multi-disability to change their negative 
attitudes towards others in the local community arithmetic average ( 2.65), and came second The programs increased multi-disability selfconfidence in the local community with arithmetic average (2.49), and finally, multi-disability now take part in the local community activities with arithmetic average (2.4).

Table (6) giving multi-disability new experiences and skills.

\begin{tabular}{|c|c|c|c|c|c|c|c|}
\hline \multirow[t]{2}{*}{ No } & \multirow[t]{2}{*}{ Phrases } & \multicolumn{3}{|c|}{$\begin{array}{l}\text { multi-disability } \\
\mathrm{N}=(55)\end{array}$} & \multicolumn{3}{|c|}{$\begin{array}{l}\text { heads of families } \\
\qquad \mathrm{N}=(55)\end{array}$} \\
\hline & & $\overline{\mathrm{A}}$ & $\bar{\sigma}$ & order & $\overline{\mathrm{A}}$ & $\bar{\sigma}$ & order \\
\hline$\overline{1}$ & $\begin{array}{lr}\text { The programs helped } \\
\text { multi-disability to } \\
\text { develop } \\
\text { community hobbies }\end{array}$ & 2.35 & 0.64 & 4 & 2.4 & 0.66 & 4 \\
\hline 2 & $\begin{array}{l}\text { The programs } \\
\text { developed work skills of } \\
\text { multi-disability in the } \\
\text { local community } \\
\text { institutions }\end{array}$ & 2.51 & 0.69 & 1 & 2.51 & 0.69 & 1 \\
\hline 3 & $\begin{array}{l}\text { The programs } \\
\text { developed } \\
\text { disability art } \\
\text { communiti- of } \\
\begin{array}{l}\text { others in the local } \\
\text { community }\end{array}\end{array}$ & 2.18 & 0.67 & 5 & 2.25 & 0.7 & 5 \\
\hline 4 & $\begin{array}{l}\text { The programs taught } \\
\text { multi-disability how to } \\
\text { market their products in } \\
\text { the local community }\end{array}$ & 2.4 & 0.71 & 3 & 2.44 & 0.71 & 3 \\
\hline 5 & $\begin{array}{l}\text { The programs increased } \\
\text { investment of multi- } \\
\text { disability abilities in the } \\
\text { implementation of } \\
\text { community activities }\end{array}$ & 2.42 & 0.66 & 2 & 2.45 & 0.66 & 2 \\
\hline Tot & 1 Dimension & 2.37 & 0.43 & $\begin{array}{l}\text { High } \\
\text { level }\end{array}$ & 2.41 & 0.46 & $\begin{array}{l}\text { High } \\
\text { level }\end{array}$ \\
\hline
\end{tabular}

The previous table shows that: The level of giving multi-disability new experiences and skills as specified by multi-disability is high with arithmetic average (2.37), :came first: The programs developed work skills of multi-disability in the local community institutions with arithmetic average (2.51) second came: The programs increased investment of multi-disability abilities in the implementation of 
community activities with arithmetic average (2.42), finally, The programs developed multi-disability art of communicating with others in the local community with arithmetic average (2.18).

-The level of giving multi-disability new experiences and skills as specified by multi-disability heads of families is high with arithmetic average (2.41),:came first: The programs developed work skills of multi-disability in the local community institutions with arithmetic average (2.41) second came: The programs increased investment of multi-disability abilities in the implementation of community activities with arithmetic average (2.45),finally, The programs developed multi-disability art of communicating with others in the local community with arithmetic average (2.25).

Table (7) satisfying the needs of as specified by multi-disability in the local community.

\begin{tabular}{|c|c|c|c|c|c|c|c|}
\hline \multirow[t]{2}{*}{ No } & \multirow[t]{2}{*}{ Phrases } & \multicolumn{3}{|c|}{$\begin{array}{l}\text { multi-disability } \\
\qquad \mathrm{N}=(55)\end{array}$} & \multicolumn{3}{|c|}{$\begin{array}{l}\text { heads of families } \\
\qquad \mathrm{N}=(55)\end{array}$} \\
\hline & & A & $\sigma$ & order & A & $\sigma$ & order \\
\hline 1 & $\begin{array}{l}\text { Multi-disability now feel } \\
\text { socially safe in the local } \\
\text { community }\end{array}$ & 2.49 & 0.6 & 2 & 2.58 & 0.57 & 1 \\
\hline 2 & $\begin{array}{l}\text { Multi-disability became } \\
\text { involved in community } \\
\text { events }\end{array}$ & 2.49 & 0.57 & 1 & 2.53 & 0.57 & 2 \\
\hline 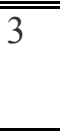 & $\begin{array}{l}\text { The programs taught multi- } \\
\text { disability sound healthy habits } \\
\text { in the local community }\end{array}$ & 2.33 & 0.58 & 5 & 2.36 & 0.59 & 5 \\
\hline 4 & $\begin{array}{l}\text { The programs enabled multi- } \\
\text { disability to participate in } \\
\text { sports tournaments at the } \\
\text { Republic level }\end{array}$ & 2.35 & 0.73 & 4 & 2.42 & 0.71 & 3 \\
\hline 5 & $\begin{array}{l}\text { The programs enabled multi- } \\
\text { disability to develop their } \\
\text { abilities to achieve self- } \\
\text { actualization in front of others }\end{array}$ & 2.36 & 0.68 & 3 & 2.38 & 0.68 & 4 \\
\hline \multicolumn{2}{|c|}{ Total Dimension } & 2.4 & 0.31 & $\begin{array}{l}\text { High } \\
\text { level }\end{array}$ & 2.45 & 0.35 & $\begin{array}{l}\text { High } \\
\text { level }\end{array}$ \\
\hline
\end{tabular}

The previous table shows that :The level of satisfying the needs as specified by multi-disability is high with arithmetic average (2.4), first came: Multi-disability now feel socially safe in the local community with arithmetic average (2.49) and Standard deviation(0.57), second came: Multi-disability became involved in 
community events with arithmetic average (2.49), and Standard deviation(0.6), finally The programs taught multi-disability sound healthy habits in the local community with arithmetic average (2.33).

- The level of satisfying the needs as specified by multi-disability heads of families is high with arithmetic average (2.45), first came: Multi-disability now feel socially safe in the local community with arithmetic average (2.58) , second came: Multi-disability became involved in community events with arithmetic average (2.53), finally The programs taught multi-disability sound healthy habits in the local community with arithmetic average (2.36).

Table (8) facing the problems of multi-disability in the local community.

\begin{tabular}{|c|c|c|c|c|c|c|c|}
\hline \multirow[t]{2}{*}{ No } & \multirow[t]{2}{*}{ Phrases } & \multicolumn{3}{|c|}{$\begin{array}{l}\text { multi-disability } \\
\mathrm{N}=(55)\end{array}$} & \multicolumn{3}{|c|}{$\begin{array}{c}\text { heads of families } \\
\mathrm{N}=(55)\end{array}$} \\
\hline & & $\mathrm{A}$ & $\sigma$ & order & $\bar{A}$ & $\sigma$ & Order \\
\hline 1 & $\begin{array}{l}\text { The programs gave } \\
\text { multi-disability more } \\
\text { ability to have sound } \\
\text { thinking to solve their } \\
\text { community problems }\end{array}$ & 2.51 & 0.57 & 2 & 2.58 & 0.57 & 2 \\
\hline 2 & $\begin{array}{l}\text { The programs helped } \\
\text { multi-disability deal } \\
\text { with their personal } \\
\text { problems in the local } \\
\text { community }\end{array}$ & 2.38 & 0.59 & 3 & 2.42 & 0.6 & 3 \\
\hline 3 & $\begin{array}{l}\text { The programs enabled } \\
\text { multi-disability to take } \\
\text { appropriate decisions to } \\
\text { solve their community } \\
\text { problems }\end{array}$ & 2.35 & 0.62 & 4 & 2.42 & 0.63 & 4 \\
\hline 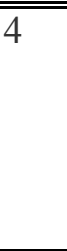 & $\begin{array}{l}\text { The programs gave multi- } \\
\text { disability the chance to } \\
\text { benefit from the } \\
\text { experience of others to } \\
\text { face their community } \\
\text { problems }\end{array}$ & 2.27 & 0.65 & 5 & 2.31 & 0.66 & 5 \\
\hline 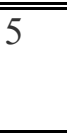 & $\begin{array}{l}\text { multi-disability are now } \\
\text { able to face their problems } \\
\text { themselves. }\end{array}$ & 2.6 & 0.6 & 1 & 2.62 & 0.59 & 1 \\
\hline$\overline{\text { Tota }}$ & "Dimension & 2.42 & 0.32 & $\begin{array}{l}\text { High } \\
\text { level }\end{array}$ & 2.47 & 0.36 & $\begin{array}{l}\text { High } \\
\text { level }\end{array}$ \\
\hline
\end{tabular}


The previous table shows that : The level of facing the problems as specified by multi-disability is high with arithmetic average (2.42), came first multi-disability are now able to face their problems themselves with arithmetic average (2.6), second was The programs gave multi-disability more ability to have sound thinking to solve their community problems with arithmetic average (2.51), and finally The programs gave multi-disability the chance to benefit from the experience of others to face their community problems with arithmetic average (2.27).

- The level of facing the problems as specified by multi-disability heads of families is high with arithmetic average (2.47), came first multi-disability are now able to face their problems themselves with arithmetic average (2.62), second was The programs gave multidisability more ability to have sound thinking to solve their community problems with arithmetic average (2.58), and finally The programs gave multi-disability the chance to benefit from the experience of others to face their community problems with arithmetic average (2.31).

Table (9) the level of the effectiveness of NGOs programs in the integration of multi-disability into the local community $(N=28)$

\begin{tabular}{|c|c|c|c|c|}
\hline No & Phrases & $\begin{array}{l}\text { The arithmetic } \\
\text { Average }\end{array}$ & $\begin{array}{l}\text { Standard } \\
\text { deviation }\end{array}$ & order \\
\hline 1 & $\begin{array}{l}\text { The programs enabled multi-disability } \\
\text { to have self-confidence }\end{array}$ & 2.64 & 0.49 & 7 \\
\hline 2 & $\begin{array}{l}\text { The programs help multi-disability to } \\
\text { develop their available skills. }\end{array}$ & 2.75 & 0.44 & 3 \\
\hline 3 & $\begin{array}{l}\text { The programs help multi-disability to } \\
\text { take responsibility according to their } \\
\text { potential and abilities. }\end{array}$ & 2.71 & 0.46 & 4 \\
\hline 4 & $\begin{array}{l}\text { The programs highlight the } \\
\text { experiences and skills of multi- } \\
\text { disability and employ them properly. }\end{array}$ & 2.82 & 0.39 & 1 \\
\hline 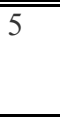 & $\begin{array}{l}\text { The programs modify the negative } \\
\text { attitudes of multi-disability towards } \\
\text { their local community. }\end{array}$ & 2.61 & 0.57 & 8 \\
\hline 6 & $\begin{array}{l}\text { The programs develop multi-disability } \\
\text { knowledge related to the development } \\
\text { of the local community }\end{array}$ & 2.79 & 0.42 & 2 \\
\hline 7 & $\begin{array}{l}\text { The programs work to make the } \\
\text { family aware of how to deal with } \\
\text { problems of multi-disability }\end{array}$ & 2.68 & 0.48 & 6 \\
\hline 8 & $\begin{array}{l}\text { The programs satisfy multi-disability } \\
\text { (social-psycho - cultural......etc) }\end{array}$ & 2.71 & 0.49 & 5 \\
\hline \multicolumn{2}{|c|}{ Total variant } & 2.71 & 0.16 & $\begin{array}{l}\text { High } \\
\text { level }\end{array}$ \\
\hline
\end{tabular}




\begin{tabular}{||lcc|}
\hline \multicolumn{2}{|l|}{ Egyptian Journal of Social Work (EJSW) } & http://ejsw.journals.ekb.eg \\
Print ISSN: 2356-9204 & Online ISSN: 2356-9212 & Vol 8, Issue 1, June 2019 \\
\hline \hline
\end{tabular}

The previous table shows that: The level of the effectiveness of NGOs programs as specified by service providers is high with arithmetic average(2.71),first came:The programs highlight the experiences and skills of multi-disability and employ them properly, with arithmetic average(2.82),second came: The programs develop multi-disability knowledge related to the development of the local community, with arithmetic average(2.79),finally :The programs modify the negative attitudes of multi-disability towards their local community, with arithmetic average(2.61).

*The results related to testing hypotheses of the study: Table (10) the level of the effectiveness dimensions of NGOs programs in the integration of multi-disability into the local community

\begin{tabular}{|c|c|c|c|c|c|c|c|}
\hline \multirow[t]{2}{*}{ No } & \multirow[t]{2}{*}{ Phrases } & \multicolumn{3}{|c|}{$\begin{array}{l}\text { multi-disability } \\
\mathrm{N}=(55)\end{array}$} & \multicolumn{3}{|c|}{$\begin{array}{l}\text { heads of families } \\
\qquad N=(55)\end{array}$} \\
\hline & & A & $\sigma$ & order & A & $\sigma$ & order \\
\hline 1 & $\begin{array}{l}\text { Changing behavior patterns } \\
\text { of persons with multiple } \\
\text { disabilities in the local } \\
\text { community. }\end{array}$ & 2.45 & 0.33 & 2 & 2.51 & 0.35 & 1 \\
\hline 2 & $\begin{array}{l}\text { developing the knowledge } \\
\text { of persons with multiple } \\
\text { disabilities in the local } \\
\text { community. }\end{array}$ & 2.41 & 0.3 & 4 & 2.45 & 0.33 & 4 \\
\hline 3 & $\begin{array}{l}\text { modifying the attitudes of } \\
\text { persons with multiple } \\
\text { disabilities towards the } \\
\text { local community. }\end{array}$ & 2.45 & 0.31 & 1 & 2.49 & 0.35 & 2 \\
\hline 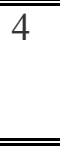 & $\begin{array}{lcc}\text { Giving } & \text { persons } & \text { with } \\
\text { multiple disabilities } & \text { new } \\
\text { experiences and skills. } & \\
\end{array}$ & 2.37 & 0.43 & 6 & 2.41 & 0.46 & 6 \\
\hline 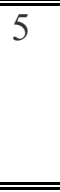 & $\begin{array}{l}\text { satisfying the needs of } \\
\text { persons with multiple } \\
\text { disabilities in the local } \\
\text { community. }\end{array}$ & 2.4 & 0.31 & 5 & 2.45 & 0.35 & 5 \\
\hline 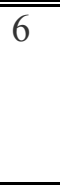 & $\begin{array}{l}\text { facing the problems of } \\
\text { persons with multiple } \\
\text { disabilities in the local } \\
\text { community. }\end{array}$ & 2.42 & 0.32 & 3 & 2.47 & 0.36 & 3 \\
\hline & 1 effectiveness dimensions & 2.42 & 0.21 & $\begin{array}{l}\text { High } \\
\text { level }\end{array}$ & 2.46 & 0.27 & $\begin{array}{l}\text { High } \\
\text { level }\end{array}$ \\
\hline
\end{tabular}


The previous table shows that: The level of the effectiveness dimensions of NGOs programs as specified by multi-disability is high with arithmetic average (2.42), first: modifying the attitudes of multidisability towards the local community with arithmetic average 2.45 ) and standard deviation (0.31), second :Changing behavior patterns of multi-disability in the local community with arithmetic average (2.45) and standard deviation (0.33), and finally :Giving multi-disability new experiences and skills with arithmetic average (2.37).

- The level of the effectiveness dimensions of NGOs programs as specified by multi-disability heads of families is high with arithmetic average (2.46), first: Changing behavior patterns of multi-disability in the local community with arithmetic average (2.51), second : modifying the attitudes of multi-disability towards the local community with arithmetic average (2.49), and finally :Giving multidisability new experiences and skills with arithmetic average (2.41). Which makes us accept the first hypothesis of the study, which means it is expected that the level of the effectiveness dimensions of NGOs programs in the integration of multi-disability into the local community is high.

Table (11) the abstract differences between the responses of multidisability and those of heads of families concerning estimating the level of the effectiveness dimensions of NGOs programs in the integration of multi-disability into the local community using $\mathrm{T}$ Test. $(\mathbf{N}=110)$

\begin{tabular}{|c|c|c|c|c|c|c|c|c|}
\hline No & Dimensions & $\begin{array}{l}\text { Research } \\
\text { society }\end{array}$ & $\begin{array}{l}\text { Number } \\
(\mathrm{N})\end{array}$ & $\begin{array}{l}\text { arithmetic } \\
\text { average }\end{array}$ & $\begin{array}{l}\text { Standard } \\
\text { deviation }\end{array}$ & $\begin{array}{c}\begin{array}{c}\text { Degrees } \\
\text { of } \\
\text { freedom } \\
\text { (df) }\end{array} \\
\end{array}$ & $\begin{array}{c}\mathrm{T} \\
\text { value }\end{array}$ & indication \\
\hline \multirow[b]{2}{*}{1} & \multirow{2}{*}{$\begin{array}{c}\text { Total } \\
\text { effectiveness } \\
\text { dimensions }\end{array}$} & $\begin{array}{c}\text { multi- } \\
\text { disability }\end{array}$ & 55 & 2.42 & 0.21 & \multirow{2}{*}{108} & \multirow{2}{*}{0.988} & \multirow{2}{*}{$\begin{array}{c}\text { No } \\
\text { indication }\end{array}$} \\
\hline & & $\begin{array}{l}\text { heads of } \\
\text { families }\end{array}$ & 55 & 2.46 & 0.27 & & & \\
\hline
\end{tabular}

The previous table shows that: There there are no substantial differences giving statistics indication between the responses of multidisability and those of heads of families concerning estimating the level of the effectiveness dimensions of NGOs programs in the integration of multi-disability into the local community, which makes us accept the second hypothesis of study that " There there are no substantial differences giving statistics indication between the responses of multi-disability and those of heads of families concerning estimating the level of the effectiveness dimensions of NGOs programs in the integration of multi-disability into the local community". 
Table (12) analysis of the variation of NGOs programs provided for multi-disability in the local community according to responses of multi-disability in NGOs, Using test One Way ANOVA . $(\mathrm{N}=$ 55)

\begin{tabular}{|c|c|c|c|c|c|c|c|}
\hline No & Dimensions & $\begin{array}{l}\text { Source of } \\
\text { variation }\end{array}$ & $\begin{array}{l}\text { Total } \\
\text { of } \\
\text { squares }\end{array}$ & $\begin{array}{l}\text { Degrees } \\
\text { of } \\
\text { freedom } \\
\text { (df) }\end{array}$ & $\begin{array}{l}\text { Average } \\
\text { of } \\
\text { Squares }\end{array}$ & $\begin{array}{c}\mathrm{F} \\
\text { Value }\end{array}$ & indication \\
\hline \multirow{3}{*}{1} & \multirow{3}{*}{$\begin{array}{c}\text { Total } \\
\text { programs }\end{array}$} & $\begin{array}{l}\text { Variation } \\
\text { between } \\
\text { groups }\end{array}$ & 0.015 & 3 & 0.005 & \multirow{3}{*}{$\begin{array}{c}1 . \\
593\end{array}$} & \multirow{3}{*}{$\begin{array}{c}\text { No } \\
\text { indication }\end{array}$} \\
\hline & & $\begin{array}{l}\text { Variation } \\
\text { inside } \\
\text { groups }\end{array}$ & 0.157 & 51 & \multirow[t]{2}{*}{0.003} & & \\
\hline & & Total & $\overline{0.172}$ & $\overline{54}$ & & & \\
\hline
\end{tabular}

The previous table shows that :There are no substantial differences giving statistics indication between the responses of multi-disability in NGOs concerning estimating NGOs programs provided for multidisability in the local community. That makes us accept the third hypothesis of study that "There are no substantial differences giving statistics indication between the responses of multi-disability in NGOs concerning estimating NGOs programs provided for multidisability in the local community."

Table (13) analysis of the variation of the level of the effectiveness dimensions of NGOs programs in the integration of multidisability into the local community according to responses of multi-disability in NGOs(*) Using test One Way ANOVA . $(\mathbf{N}=55)$

\begin{tabular}{|c|c|c|c|c|c|c|c|}
\hline No & Dimensions & $\begin{array}{c}\text { Source of } \\
\text { variation }\end{array}$ & $\begin{array}{l}\text { Total of } \\
\text { squares }\end{array}$ & $\begin{array}{c}\text { Degrees } \\
\text { of } \\
\text { freedom } \\
\text { (df) }\end{array}$ & $\begin{array}{c}\text { Average } \\
\text { of } \\
\text { Squares }\end{array}$ & $\begin{array}{c}\mathrm{F} \\
\text { Value }\end{array}$ & indication \\
\hline \multirow{3}{*}{1} & \multirow{3}{*}{$\begin{array}{c}\text { Total } \\
\text { effectiveness } \\
\text { dimensions }\end{array}$} & $\begin{array}{c}\text { Variation } \\
\text { between } \\
\text { groups }\end{array}$ & 0.181 & 3 & 0.060 & \multirow{3}{*}{1.378} & \multirow{3}{*}{$\begin{array}{c}\text { No } \\
\text { indication }\end{array}$} \\
\hline & & $\begin{array}{l}\text { Variation } \\
\text { inside } \\
\text { groups }\end{array}$ & 2.228 & 51 & \multirow[t]{2}{*}{0.044} & & \\
\hline & & Total & 2.408 & $\begin{array}{l}54 \\
\end{array}$ & & & \\
\hline
\end{tabular}

The previous table shows that: there are there are no substantial differences giving statistics indication between the responses of multi-disability in NGOs concerning estimating the 
level of the effectiveness dimensions of NGOs programs in the integration of multi-disability into the local community. That makes us accept the fourth hypothesis of study that "there are there are no substantial differences giving statistics indication between the responses of multi-disability in NGOs concerning estimating the level of the effectiveness dimensions of NGOs programs in the integration of multi-disability into the local community."

\section{*General Discussion of the Research Issues in Light of the Derived Results:}

This study has proven its objectives and its supposition which it seeks to achieve. It has proved that there are a lot of programs NGOs provide to multi-disability, which help to them integrate into the community such as educational, social, entertaining, health, and economic programs, which the study of ( Manal Talat Mahoud 2008) has proved as it confirmed that NGOs provide to multi-disability different programs such as, social and entertaining programs ,also educational programs, in addition to programs of community integration and helping multi-disability in a way that contributes to their integration into the local community .

The results of the study are associated with the effectiveness model indexes (Rino J. Patti1987) which included several dimensions proved by the study which are:

-The results of the study showed that the effectiveness of NGOs programs contributing to their integration into the local community is high as it modifies the attitudes of multi-disability towards the local community. The study results of both (Max filed 1995) (Michael, 1., 2002) have shown that NGOs provide social support for multidisability socially, economically and politically as individuals within the local community by providing them real opportunities to strengthen and protect their rights and express their views which helps modify their negative attitudes towards their community and participate in various community activities.

- The results of the study have proved the effectiveness of those programs contribute to changing behavior patterns of multi-disability in the local community and this was demonstrated by the results of the study (Seals, Janet 1997) where it proved that violent behaviors have become almost non-existent in multi-disability children by providing jobs and socialization of these Children, they became emotional equilibrium in their community dealings and respect opinions of others when discussing community issues. 
- The results of the study have also proved the effectiveness of the programs offered by NGOs to multi-disability help to face their problems in the local community and this was demonstrated by the results of the study of (Abdel-Wanis Mohamed Al-Rashidi 2006) which has shown the need to provide various programs for multidisability, and helping them communicate with others to benefit from their expertise in solving their problems and give them an opportunity to express their problems and take appropriate decisions to face them, that is besides providing the appropriate educational programs to their abilities that give them different societal experiences.

- The results of the study also proved that the effectiveness of the programs contribute to the development of the community knowledge for multi-disability that was demonstrated by the results of the study (Hinton, s., 2002) that NGOs contribute to provide multi-disability of different knowledge about issues related to their own community and its current events, also work to eradicate their community illiteracy concerning getting their rights.

- The effectiveness of the programs contributes to satisfying the needs multi-disability in local community and that was demonstrated by the results of the study (Deborah Valentine 1992) which demonstrated that the general practice of social service work to help multi-disability to satisfy their needs and reduce the sense of isolation and increase opportunities for having successful relationships with the social environment.

- Finally, the effectiveness of the programs contribute to giving multidisability new experiences and skills .The study of ( Abdel Ghafar,Abdel Aziz Ibrahim 2008) has highlighted the importance of taking care of the disabled and developing their experiences and skills and creating job opportunities helping them to have the suitable work for their abilities and energies and communicating with others in the community which enables them to integrate into the society. As a result of the foregoing, it makes us accept the first hypothesis of the study.

The study has also proved that there are no substantial differences giving statistics indication between the responses of multidisability and the responses of heads of families concerning estimating the level of the effectiveness dimensions NGOs programs in the integration of persons with multiple disabilities into the local community, "As the researchers' responses were similar, and there may be almost an agreement in their responses on the types of 
programs they get from NGOs and help them to integrate into society with, what makes us accept the second hypothesis of the study. The results of the study have also proved that there are no substantial differences giving statistics indication between the responses of the multi-disability in NGOs concerning identification of the programs of NGOs provided multi-disability in the local community. That makes us accept the third hypothesis of the study. The results of the study have also proved that there are no substantial differences giving statistics indication between the responses of the multi-disability in NGOs concerning estimating the level of the effectiveness dimensions of NGOs programs in the integration of multi-disability into the local community, and this may reflect the satisfaction of multi-disability with the programs provided by these organizations in a way that enables them to integrate into and participate in the local community ,which makes us accept the fourth hypothesis of the study.

Finally, the study has also proved that the level of the effectiveness of NGOs programs in the integration of multi-disability into the local community as specified be service providers is high, and this has been proved by the study (seeger Augustine 2008), and the professional role of the social workers (service providers) is achieving the first integration processes for multi-disability , giving them experience and self-confidence, modifying their negative attitudes, facing their problems, satisfying their needs and developing their life experiences and skills so they are able to take part in the society developing programs.

\section{* Recommendations of the study:}

Studying the efficiency indexes of multi-disability organizations and their usefulness of providing services to this section, studying the problems facing multi-disability families, and the problems facing the social workers when dealing with multi-disability, studying the obstacles of the effectiveness of the programs of multidisability organizations, studying multi-disability needs. 


\section{References}

Abdul Ghaffar, A, I, (2008): social support and social rehabilitation of disabled persons, a research published in the 21st International Conference of Social Work, Volume 12, Faculty of social work, Helwan University.

- Abu AlNaser, M ,M. (2004): rehabilitation and caring of disability challengers, Cairo, Etrac for Printing \& Publication.

- Al khateeb, Abdul Rahman (2006): Integrated social service in the field of disability and persons with special needs, Cairo, The Anglo Egyptian Bookshop.

- Al Rasheedi , A ,M (2006): Requirements of planning to encounter social exclusion of persons with multiple disabilities as an introduction to improve their life quality, a research published in journal of Studies in Social Sciences and Humanities, issue 27, Part 5, Faculty of social work, Helwan University.

- Al Sherbini , M,K, (2011): The relation between use of rational emotive behaviortherapy in at service of individuals and changing negative trends towards incorporation of disabled persons in ordinary schools, published research, Journal of Studies in Social Work, Helwan University, Faculty of Social Work, Issue 30, Part3.

- Al Sourogi, T, M,\& AbulMaati, M, A, (2006): fields of social work practice, Alexandria, Modern University Office.

- Al Zayyat, F,M, (2009): Incorporation of persons with special needs "philosophy, approach, and mechanisms", Cairo, University Press.

○ Brker, R,. (199); The social work Dictionary, Nasw- V.S.A .

- Central Agency for Public Mobilization and Statistics (2017): Statistical book, Cairo.

○ Cook, M., \& pamele, T., (2002): Abuse and disabled children, Journal of learning Children Disabilities, vol (11), No (1).

- David, R, \& Others(2001): Program Evaluation An Introduction U.S.A Brooks Cole, Third Edition.

- Davie d, l., (2002): The role of civil society in the development policy with Multi disability, MSW, California university, united state.

- Deborah , V (1992) : Social Work Practice With Handicapped, Dept Social Work, Ohio University, PHD.

- Douglas , Gexer (2006): parental satisfaction with integrated early childhood programs, EdD, Columbia University Teacher College.

- Ecken rode, J., etal (2008): School performance and disciplinary problems among A bused and Neglected children, Journal of development \& psychology, V (29) No(1).

- Fahmi, M, S, (2000): the reality of care of persons with disabilities, Alexandria, Modern University Office.

- Ghobari, M, S,. (2003): Care of special groups in field of social service, Alexandria, Modern University Office. 
- Hasan , S, K,. (2012): disability on Egypt is a social and economic issue, a research published in the Central Administration of Human Resources \& Transparency, Central Agency For Organization \& Administration, Cairo.

- Hinton, s., (2002): NON Governmental organization with Multi disability, PHD California university, united state.

○ Janet, W., \& Frank, k., (2006): Learning disabilities and related disorders (Characteristics and teaching strategies), USA, Boston, p5

- Joem, Schriver (2004) :Human Behavior and social Environment, U.S.A,Pearson Education .

○ John, M.,(2002): Guiding families from disability a ware in action personal correspondence intervention in hode island, journal of rehabitation \& disabilities, $\operatorname{Vol}(8), \operatorname{No}(6)$.

○ Khawla , Y , H,. \& Cristina, S,. (2013) :MULTI disable people needs profile-acomprehensive approach,European Scientific Journal.

○ Lucile, G-Janet (2015): Multipe Disabilities (International Encyclopedia of Rehabilitation) Ancien directeur medical du CESAP, pour la Fondation HANDAS (Handicaps Associes.

- Manqarious, Naseef (2004): modern trends and field applications in care of persons with special needs,Alexandria, Modern University Office.

○ Michael, k., (2004): Evaluating a medical home and community based physical disability, PHD, Duquesne university, Pennsylvania.

- Michael, l., (2002): Freedom of Expression human rights for multi disability, MSW, international university, united state.

○ Penn , M, P,. (1995): Dutrggling alone the lives and clinical statues of the mentally disabled in the community Menlally retarded rehabilitation, Public policy Psychology London University of Community.

- Rino J. Patti(1987) ; Managing for services effectivenssins social welfer organizations in social work (Journal of the national association of social workers, volume32, nomber5.

- Roos , M, (1995):community organization and practice (M.Y. herper and Brath EsE.

- Seals , J, L, (1997) :Effect of ecological variables on the behavioral adaptations of site adjustments for astudent with multiple disabilities,United States,AnnArbor, M.A., California, State University, Fresno.

- seeger, A, B (2008) : An integrated Primary care demonstration Project (united states; spealding university .

- Shalabi, Naeem ,A (2007): Effectiveness of general practice in service of individuals to mitigate the severity of social relation problems of families of children with multiple disabilities, a research published in the twentieth international conference, Helwan University, F, of Social Work. 
○ Stanley, f., \& stcrst, A., (1993): Learning disabilities, USA, brooks cole.

○ Talaat, M,. (2008): empowerment of persons with multiple disabilities to improve their life quality, a research published in the $21 \mathrm{st}$ International Conference of Social Work, Volume 2, Faculty of social work, Helwan University.

○ World Health Organization (2012): http://www.webteb.com/article15011. 
